\title{
Viral Respiratory Infections with Bocavirus in Romania
}

Cristina Tecu ${ }^{1 *}$, Maria Elena Mihai ${ }^{1}$, Viorel Alexandrescu${ }^{1}$, Alina Ivanciuc ${ }^{1}$, Gheorghe Necula ${ }^{1}$, Emilia lupulescu${ }^{1}$ and Odette Popovici ${ }^{2}$

${ }^{1}$ NIRDMI Cantacuzino, Romania

${ }^{2}$ National Center for Communicable Disease Surveillance and Control, Romania

\begin{abstract}
Human Bocavirus was described in 2001 by Tobias Allander et al. (Karolinska University Hospital, Stockholm, Sweden) in nasopharyngeal aspirates collected from children with acute respiratory infections. The technique used was a random PCR cloning sequencing, observing that there is a new DNA virus identified in 17 of 540 samples (3, $1 \%)$.

Full spectrum of diseases associated with human Bocavirus (BoV), remains to be defined. Presence of the virus in respiratory secretions, serum, and stool suggests that may cause systemic diseases.

Bocavirus belongs to Parvoviridae family and is a single-stranded DNA virus.

Analyzed samples in our study were nasopharyngeal exudates collected from 309 patients aged 19 days-96 years, hospitalized with a diagnosis of SARI (Severe Acute Respiratory Infections) in hospitals from eight counties and Bucharest in September 2011-September 2012.

Diagnostic method used to detect human BoV was Multiplex RT-PCR (Reverse Transcription-Polymerase Chain Reaction) with Seeplex 15 One Step RV ACE Detection Kit.

Of the 309 samples tested, 10 were positive for human Bocavirus. All 10 samples were collected from children (7 months-3.5 years) with bronchiolitis and pneumonia without gastrointestinal manifestations.

The conclusions observed from the data analysis were:

HumanBoV is also present in Romania, meeting at young ages children.

The percent of 3,3\% is similar to that found in Sweden, but lower than in Jordan (9\%), China (7\%) and Taiwan $(5,6 \%)$.

Symptoms of patients hospitalized and diagnosed with BoV were only respiratory (LRTI-lower respiratory tract infections) and no digestive.

BoV positive cases were not associated with others viruses.
\end{abstract}

Keywords: Human Bocavirus; RT-PCR; Bronchiolitis; SARI

\section{Introduction}

Allander et al. at the Karolinska Institutet in Stockhlom, Sweden, first cloned this new member of the family of Parvoviridae in 2005 from pooled nasopharyngeal aspirates (NPA, collection of aspirated fluid from the back of the nasal cavity) [1]. They used a novel technique called molecular virus screening, based on random cloning and bioinformatical analysis. This technique has led to the discovery of new viruses such as polyomavirus KI (Karolinska Institute) [2] and WU (Washington University) [3], which are closely related to each other and have been isolated from respiratory secretions.

The name BocaVirus is derived from Bovine and CAnine, referring to the known hosts for other members of this genus; the bovine parvovirus which infects cattle and the minute virus of canines which infects dogs [4].

Parvoviruses (Latin: small viruses) have a 5 kilobase long single stranded DNA.

Full spectrum of diseases associated with human BoV remains to be defined. Presence of the virus in respiratory secretions, serum, and stool suggests that may cause systemic diseases.

The aim of the study was to find that $\mathrm{BoV}$ is also present in Romania.

\section{Materials and Methods}

The study was part of the SARI (Severe Acute Respiratory Infections) surveillance system which has been set up in Romania since 2009. During the season 2011-2012, the surveillance system comprised 26 hospitals (in Bucharest and 8 counties). The case definition of SARI [5] for the patient's $\geq 5$ years old (with onset during the previous 7 days before hospitalization) consists of: fever $>38^{\circ} \mathrm{C}$, AND cough or sore throat, AND shortness of breath or difficulty breathing.

Case definition of SARI in children $<5$ years old is the definition for pneumonia and severe pneumonia [5] (Table 1). The SARI system was developed under the coordination of National Centre for Surveillance and Control of Communicable disease and National

*Corresponding author: Cristina Tecu, Spl. Independentei 103, CP 1-525, 050096, sector 5 Bucharest, Romania;Tel: 0040749032041; E-mail: tecucristina@ yahoo.com

Received April 19, 2013; Accepted July 11, 2013; Published July 15, 2013

Citation: Tecu C, Mihai ME, Alexandrescu V, Ivanciuc A, Necula G, et al. (2013) Viral Respiratory Infections with Bocavirus in Romania. J Medical Microbio Diagnosis S1: 006. doi:10.4172/2161-0703.S1-006

Copyright: @ 2013 Tecu C, et al. This is an open-access article distributed under the terms of the Creative Commons Attribution License, which permits unrestricted use, distribution, and reproduction in any medium, provided the original author and source are credited. 
Citation: Tecu C, Mihai ME, Alexandrescu V, Ivanciuc A, Necula G, et al. (2013) Viral Respiratory Infections with Bocavirus in Romania. J Medical Microbiol Diagnosis S1: 006. doi:10.4172/2161-0703.S1-006

Page 2 of 3

\begin{tabular}{|c|c|c|c|}
\hline \multirow[t]{2}{*}{ Age } & \multicolumn{3}{|c|}{ Diseases } \\
\hline & Severe Pneumonia & Very Severe Pneumonia & Bronchiolitis of infancy \\
\hline Children below 2 months & $\begin{array}{l}\text { - symptoms: cough or difficult breathing and } \\
\text { - signs: } 60 \text { or more breaths per minute, or severe } \\
\text { chest indrawing } \\
\text { - and no general danger signs (the sign 'stopped } \\
\text { feeding well' in young infants replaces 'unable } \\
\text { to drink' of the older children as a danger sign), } \\
\text { wheezing, stridor in calm child or fever or low } \\
\text { body temperature }\end{array}$ & $\begin{array}{l}\text { - symptoms: cough or difficult breathing } \\
\text { - and signs: general danger signs, wheezing, } \\
\text { stridor in a calm child or fever or low body } \\
\text { temperature }\end{array}$ & $\begin{array}{l}\text { - Clinically diagnosed respiratory condition } \\
\text { presenting with breathing difficulties, cough, } \\
\text { poor feeding, and irritability and, in the } \\
\text { very young, apnea. These clinical features, } \\
\text { together with wheeze and/or crepitations on } \\
\text { auscultation combine to make the diagnosis. } \\
\text { - bronchiolitis most commonly presents in } \\
\text { infants aged three to six months }\end{array}$ \\
\hline \multirow{2}{*}{$\begin{array}{l}\text { Children } 2 \text { months up to } \\
5 \text { years old }\end{array}$} & Pneumonia & Severe pneumonia & \\
\hline & $\begin{array}{l}\text { - symptoms: cough or difficult breathing } \\
\text { - and signs: } 50 \text { or more breaths per minute for } \\
\text { infants age } 2 \text { months up to } 1 \text { year, or } 40 \text { or more } \\
\text { breaths per minute for children age } 1 \text { up to } 8 \\
\text { years old } \\
\text { - and no chest indrawing, general danger signs, } \\
\text { stridor in calm child or severe malnutrition }\end{array}$ & $\begin{array}{l}\text { - symptoms: cough or difficult breathing } \\
\text { and signs: chest indrawing } \\
\text { - and no general danger signs, stridor in a } \\
\text { calm child or severe malnutrition }\end{array}$ & \\
\hline
\end{tabular}

Table 1: Case definition of pneumonia [5] and Bronchiolitis [6].

\begin{tabular}{|l|c|}
\hline Total samples ILI & 755 \\
\hline Influenza virus A/H3 & 216 \\
\hline$\% \mathrm{H} 3$ & 97.74 \\
\hline Influenza virus B & 5 \\
\hline$\%$ B & 2.26 \\
\hline Influenza virus A/H1 & 0 \\
\hline Total pos & 221 \\
\hline$\%$ pos & 29.27 \\
\hline
\end{tabular}

Table 2: Typing and subtyping results of positive detected samples in ILI cases in 2011-2012 influenza seasons.

\begin{tabular}{|l|c|}
\hline Total SARI 2011-2012 & 309 \\
\hline Poz & 163 \\
\hline$\%$ poz & 52.7 \\
\hline RSV & 40 \\
\hline Parainfluenza & 23 \\
\hline ADV & 6 \\
\hline hMPV & 15 \\
\hline Coronavirus & 1 \\
\hline Bocavirus & 10 \\
\hline Influenza virus A/H3 & 67 \\
\hline Influenza virus B & 1 \\
\hline
\end{tabular}

Table 3: Positive detected samples in SARI cases in 2011-2012 seasons by etiological agents.

Institute of Research and Development Microbiology and Immunology Cantacuzino that performed the laboratory confirmation.

We conducted the study between September 2011 and September 2012 to find that $\mathrm{BoV}$ is also present in Romania or not.

The samples analyzed were nasal swabs from 309 patients aged 19 days-96 years which were admitted to hospitals from Bucharest and 8 counties from Romania. The samples were transported to the laboratory in viral transport medium, on the same day and processed either on the same day or stored at minus $80^{\circ} \mathrm{C}$ and processed subsequently.

Diagnostic method used to detect BoV was multiplex RT-PCR with Seeplex 15 One Step RV ACE Detection kit (South Korea). The work protocol was according to manufacturer's instructions: Seegene's Product User Manual 12/2010 V2.02. Shortly:

○ Identity samples: samples from SARI

○ Positive controls: from kit

○ Materials: RV 15 oneStep ACE Detection Seeplex kit

○ Machine: BioRad Termocycler

○ Mastermix (total volume $40 \mu \mathrm{l}$ ): Rnaze free water $-8 \mu \mathrm{l}, 8-\mathrm{MOP}$ Solution-7.5 $\mu$ l, Random Hexamer-2.5 $\mu$ l, 5×RV15 OPM-10 $\mu$ l, 5×One Step RT-PCR buffer-10 $\mu$ l, OneStep RT-PCR Enzyme Mix- $2 \mu \mathrm{l}$

○ RNA template /RNA(PC)/NC $10 \mu \mathrm{l}$

- Amplification reaction program: Revers transcription $50^{\circ} \mathrm{C}-30$, initial activation $94^{\circ}-15,45$ cycles: denaturation $94^{\circ}-30^{\prime \prime}$, annealing $60^{\circ}-1^{\prime} 30^{\prime \prime}$, extension $72^{\circ}-1$, final extension $72^{\circ}-10^{\prime}$, hold $4^{\circ}$.

- Visualization: Electrophoresis on $2 \%$ agarose gel in TBE $1 \mathrm{X}$ with $\mathrm{EtBr}$, in presence of RV15 OneStep A/B/C Markers; molecular weight marker.

\section{Results and Discussion}

In Romania, the influenza surveillance is performed by the Romanian National Public Health Institute (NPHI) in Bucharest and the National Influenza Centre (NIC) in "Cantacuzino" NIRDMI. There is a network of sentinel general practitioners (GPs) from each county (total number of GPs=313) who weekly report to NPHI the number of patients who consult them with an influenza-like illness (ILI) and a network of severe acute respiratory infections (SARI) (total number of units care=26). The specimens collected are examined at the NIC for the presence of influenza virus and other respiratory viruses.

Sentinel or non sentinel ILI samples are tested by Real Time-PCR for Influenza A and B. Positive samples for type are subtyped by RTPCR for $\mathrm{H} 1$ and $\mathrm{H} 3$. H3 positives are submitted to Real Time-PCR sw Influenza A in order to differentiated between human and swine $\mathrm{H} 3$.

Sentinel or non sentinel SARI samples are tested first by Real TimePCR for Influenza A\&B. Negative samples for Influenza A\&B are tested by Reverse Transcription-PCR for Para Influenza, RSV A\&B, hMPV, HEV, Rhinovirus, Corona virus or PCR for Adenovirus and Bocavirus.

In the 2011/12 season, from week 40 of 2011 through week 20 of 2012 , influenza viruses have been detected only sporadically throughout the country. 289 influenza viruses have been detected in 1050 clinical samples originating from patients with ILI or SARI (Table 2 and Table 3).

Distribution by age groups of SARI samples is shown in table 4 . 
Citation: Tecu C, Mihai ME, Alexandrescu V, Ivanciuc A, Necula G, et al. (2013) Viral Respiratory Infections with Bocavirus in Romania. J Medical Microbiol Diagnosis S1: 006. doi:10.4172/2161-0703.S1-006

Page 3 of 3

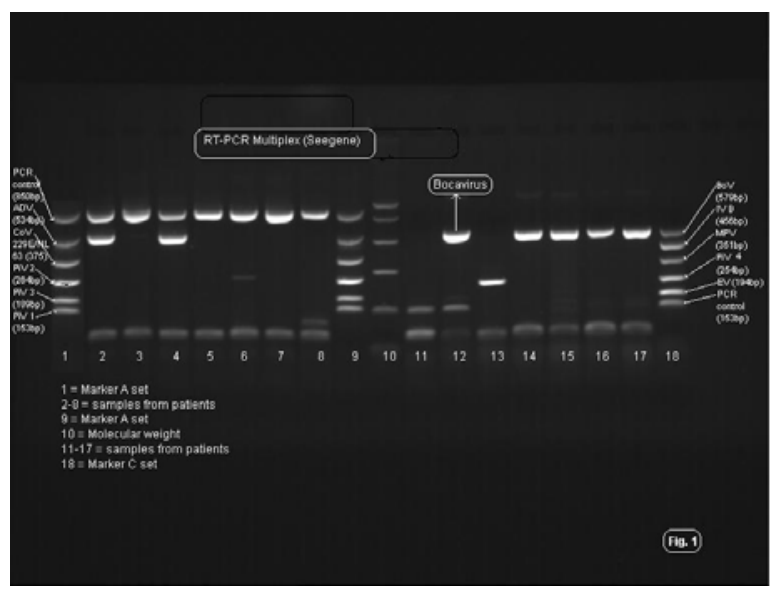

Figure 1: Positive results for humanBoV.

\begin{tabular}{|l|l|l|l|l|l|l|}
\hline & $\mathbf{0 - 4}$ ys & $\mathbf{5 - 1 4}$ ys & $\mathbf{1 5 - 2 9}$ ys & $\mathbf{3 0 - 6 4}$ ys & $\mathbf{6 5 +}$ ys & Total \\
\hline $\begin{array}{l}\text { Influenza virus } \\
\text { Positive }\end{array}$ & 10 & 6 & 21 & 25 & 6 & 68 \\
\hline $\begin{array}{l}\text { Other resp. } \\
\text { viruses pos }\end{array}$ & $\begin{array}{l}70 \\
10=\text { Bocavirus }\end{array}$ & 15 & 4 & 5 & 1 & 95 \\
\hline Negative & 60 & 39 & 24 & 20 & 3 & 146 \\
\hline Total & 140 & 60 & 49 & 50 & 10 & 309 \\
\hline
\end{tabular}

Table 4: Distribution by age of groups-SARI 2011-2012 season.

Of the 309 samples tested, 10 were positive for humanBoV (Figure 1). All samples were collected from children (7 months-3.5 years) with symptoms of bronchiolitis [4] and pneumonia [6] without gastrointestinal manifestations. The children with pneumonia had interstitial infiltrates noted by chest radiography. When characteristics of the children positive for BoV were compared with those of children with other demonstrated virus infections, no clinically significant differences were recorded.While infections with RSV peaked during the first six months of age, most BoV infections occured ot the age of 1-3 years.

Infections with BoV were found year-round, though most occured in the winter months.

Recent studies have detected BoV in 1.5\%-11.3\% of investigated respiratory tract samples in North America, Europe, Asia and Australia, suggesting that the virus has a global distribution [7-13].

The percent of 3.3\% found in our study is lower than the percent found in other countries 9\% in Jordan [14], 5.6\% in Taiwan [15]. When comparing the detection frequencies, this difference in detection methods has to be taken into consideration. In general PCR assays are more sensitive than antigen detection methods [16]. Therefore it is likely that the true prevalence of the respiratory viruses that were analyzed by IFA is actually higher than here reported. Another potential reason for differing infection frequencies between studies may be due to regional and temporal differences in the incidence of BoV infection.

\section{Conclusions}

The human BocaVirus is also present in Romania, meeting at young ages children.

The percent of 3. 3\% is similar to that found in Sweden, but lower than in other countries.
The symptoms of patients hospitalized and diagnosed with BocaVirus were only respiratory and no digestive.

Human Bocavirus positive cases were not associated with other viruses.

\section{Acknowledgments} study

We thank Romanian Novaintermed Company for financial support of this

\section{References}

1. Allander T, Tammi MT, Eriksson M, Bjerkner A, Tiveljung-Lindell A, et al. (2005) Cloning of a human parvovirus by molecular screening of respiratory tract samples. Proc Natl Acad Sci U S A 102: 12891-12896.

2. Allander T, Andreasson K, Gupta S, Bjerkner A, Bogdanovic G, et al. (2007) Identification of a third human polyomavirus. J Virol 81: 4130-4136.

3. Gaynor AM, Nissen MD, Whiley DM, Mackay IM, Lambert SB, et al. (2007) Identification of a novel polyomavirus from patients with acute respiratory tract infections. PLoS Pathog 3: e64.

4. Schwartz D, Green B, Carmichael LE, Parrish CR (2002) The canine minute virus (minute virus of canines) is a distinct parvovirus that is most similar to bovine parvovirus. Virology 302: 219-223.

5. WHO Regional Office For Europe Guidance for Sentinel Influenza Surveillance in Humans - May 2011.

6. The Scottish Intercollegiate Guidelines Network (SIGN) (Nov.2009) "Bronchiolitis in children.A national clinical guideline, 91:1.

7. Bastien N, Brandt K, Dust K, Ward D, Li Y (2006) Human Bocavirus infection Canada. Emerg Infect Dis 12: 848-850.

8. Foulongne V, Rodière $M$, Segondy $M$ (2006) Human Bocavirus in children Emerg Infect Dis 12: 862-863.

9. Ma X, Endo R, Ishiguro N, Ebihara T, Ishiko H, et al. (2006) Detection of human bocavirus in Japanese children with lower respiratory tract infections. J Clin Microbiol 44: 1132-1134.

10. Sloots TP, McErlean P, Speicher DJ, Arden KE, Nissen MD, et al. (2006) Evidence of human coronavirus HKU1 and human bocavirus in Australian children. J Clin Virol 35: 99-102.

11. Arnold JC, Singh KK, Spector SA, Sawyer MH (2006) Human bocavirus: prevalence and clinical spectrum at a children's hospital. Clin Infect Dis 43: 283 288.

12. Choi EH, Lee HJ, Kim SJ, Eun BW, Kim NH, et al. (2006) The association of newly identified respiratory viruses with lower respiratory tract infections in Korean children, 2000-2005. Clin Infect Dis 43: 585-592.

13. Weissbrich B, Neske F, Schubert J, Tollmann F, Blath K, et al. (2006) Frequent detection of bocavirus DNA in German children with respiratory tract infections. BMC Infect Dis 6: 109.

14. AL-Roussan HO, Meqdam MM, Alkhateeb A, Al-Shorman A, Quasy LM, Al-Moqbel MS (2011) "Human bocavirus in Jordan : prevalence and clinical symptoms in hospitalized paediatric patients and molecular virus characterization”. Singapore Med. J. 5295: 365-369.

15. Lin JH, Chiu SC, Lin YC, Chen HL, Lin KH, et al. (2009) Clinical and genetic analysis of Human Bocavirus in children with lower respiratory tract infection in Taiwan. J Clin Virol 44: 219-224.

16. Herrmann B, Larsson C, Zweygberg BW (2001) Simultaneous detection and typing of influenza viruses $A$ and $B$ by a nested reverse transcription-PCR: comparison to virus isolation and antigen detection by immunofluorescence and optical immunoassay (FLU OIA). J Clin Microbiol 39: 134-138. 